\title{
THE ROLE OF THE RENIN-ANGIOTENSIN SYSTEM IN THE CONTROL OF ALDOSTERONE SECRETION*
}

\author{
By JAMES O. DAVIS, PHYLLIS M. HARTROFT, ELWOOD O. TITUS, CHARLES \\ C. J. CARPENTER, CARLOS R. AYERS AND HERBERT E. SPIEGEL \\ WITH THE SURGICAL ASSISTANCE OF ALFRED CASPER AND THE \\ TECHNICAL ASSISTANCE OF ELEANOR CAVANAUGH \\ (From the Section on Experimental Cardiovascular Disease, Laboratory of Kidney and Elec- \\ trolyte Metabolism, and the Laboratory of Chemical Pharmacology, National \\ Heart Institute, Bethesda, Md.; and from the Department of Pathology, \\ Washington University School of Medicine, St. Louis, Mo.)
}

(Submitted for publication August 21, 1961 ; accepted September 18, 1961)

Within the last year, evidence (1-4) has accumulated to show that the kidney secretes a hormone which is a prime regulator of aldosterone secretion. The renal origin of an aldosteronestimulating hormone (ASH) has been demonstrated following acute blood loss (1-3), during chronic thoracic caval constriction (4), and during chronic $\mathrm{Na}$ depletion (4). Nephrectomizedhypophysectomized dogs failed to respond to acute hemorrhage with an increase in aldosterone secretion, and acute bilateral nephrectomy of hypophysectomized caval and hypophysectomized Nadepleted dogs resulted in a marked drop in aldosterone secretion. Furthermore, crude saline extracts of kidney produced a striking increase in aldosterone secretion (1-5). In malignant experimental renal hypertension, hyperaldosteronism was consistently present (6). These findings and the reports that renin preparations (6) and synthetic angiotensin II (6-8) increase the rate of aldosterone production suggest the possibility that $\mathrm{ASH}$ is renin.

The present experiments were undertaken to determine the chemical nature of this ASH by fractionation of crude kidney extracts for aldosterone-stimulating and pressor activity. The renin content of kidneys from dogs with thoracic caval constriction and secondary hyperaldosteronism and from normal dogs has been compared. Since dogs with thoracic caval constriction and $\mathrm{Na}$-depleted dogs do not have hypertension, the response in blood pressure to synthetic angiotensin

* Preliminary reports were made at the Annual Meeting of the Endocrine Society, June, 1961, and at the Fall Meeting of the American Physiological Society, September, 1961.
II was compared in these animals and in normal dogs. The renal juxtaglomerular cells have been examined for hypergranulation and hyperplasia in dogs with experimental hyperaldosteronism secondary to caval constriction. Finally, evidence has been presented as to the nature of the stimulus which elicits release of an ASH by the kidney; the acute effects of suprarenal aortic constriction on aldosterone and corticosterone secretion have been studied.

\section{METHODS}

Fractionation of crude kidney extracts. Approximately $300 \mathrm{~g}$ of fresh kidney ( 3 batches) and frozen kidney ( 8 batches) was obtained from normal dogs immediately after exsanguination. Each $300 \mathrm{~g}$ of kidney tissue was homogenized in $1,200 \mathrm{ml}$ of normal saline and the extracts were fractionated according to the scheme in Figure 1. The saline extracts of kidney were heated to $55^{\circ} \mathrm{C}$ for 10 minutes, cooled immediately to $0^{\circ} \mathrm{C}$, and centrifuged for 20 minutes at $8,000 \mathrm{G}$ at $4^{\circ} \mathrm{C}$. The $\mathrm{pH}$ of these kidney extracts was 6.2 to 6.4 . The supernatant from four of the batches from frozen kidney was assayed at this point in the fractionation scheme while the other seven lots of material were further fractionated. The supernatant from the other seven extracts was lyophilized, redissolved in $120 \mathrm{ml}$ of $0.02 \mathrm{M} \mathrm{Na}$ pyrophosphate buffer ( $\mathrm{pH}$ 5.3), and dialyzed against: 1) $900 \mathrm{ml}$ of the buffer for 4 hours, 2) $250 \mathrm{ml}$ of the buffer for a second 4 hours, 3) $250 \mathrm{ml}$ of the buffer for a third 4 hours, and 4) $6 \mathrm{~L}$ of the buffer for 15 hours. The last $6 \mathrm{~L}$ of buffer were discarded after dialysis. The first three dialysates were combined and lyophilized, and one-half of the material was assayed. The other half of the dialysate was extracted for 1 hour with two $50-\mathrm{ml}$ aliquots of 95 per cent butanol; the butanol was evaporated and the material was assayed. To one-half of the nondialyzable protein fraction which was present in about $60 \mathrm{ml}$ of pyrophosphate buffer, ammonium sulfate was added to make a $1.2 \mathrm{M}$ solution. After 30 minutes the fraction was centrifuged. The pre- 
cipitate was dissolved in $10 \mathrm{ml}$ of pyrophosphate buffer, dialyzed against $240 \mathrm{ml}$ of buffer, and the contents of the cellophane bag were assayed for activity of protein precipitated with $1.2 \mathrm{M}$ ammonium sulfate. To the supernatant from the $1.2 \mathrm{M}$ precipitation, additional ammonium sulfate was added to make a $1.7 \mathrm{M}$ concentration and the protein was separated and assayed. Similarly, a protein fraction was obtained with $2.5 \mathrm{M}$ ammonium sulfate and assayed. The material not precipitated with ammonium sulfate was dialyzed overnight against distilled water at $4^{\circ} \mathrm{C}$, lyophilized, and assayed.

Each of another four batches of $300 \mathrm{~g}$ of frozen kidneys was homogenized in $600 \mathrm{ml}$ of buffer, stored overnight at $4^{\circ} \mathrm{C}$, and centrifuged. The precipitate was washed with $300 \mathrm{ml}$ of buffer which was then added to the original supernatant. The supernatant and wash (approximately $900 \mathrm{ml}$ of solution) were lyophilized and $90 \mathrm{ml}$ of water was added to the lyophilized material. This solution was dialyzed overnight against $2 \mathrm{~L}$ of distilled water; the dialysate was lyophilized and the fraction was assayed.

The effects of heating crude kidney extracts were studied. The two kidneys from each of 8 normal dogs were homogenized in $300 \mathrm{ml}$ of normal saline. The extracts were heated to $80^{\circ} \mathrm{C}$ for 10 minutes, centrifuged, and the supernatant assayed.

All fractions were assayed for steroidogenic and pressor activity in anesthetized, hypophysectomized-nephrectomized dogs as described previously (1); an intravenous infusion of the solute in $300 \mathrm{ml}$ of normal saline was given over a period of 30 minutes. The right adrenolumbar vein was cannulated for collection of adrenal vein blood. Steroid secretion was measured by methods described previously (9-11); at least two control and two experimental collections of adrenal vein blood were made for each assay. Arterial pressure was recorded continuously by means of a Statham strain gage and a Sanborn recording system.

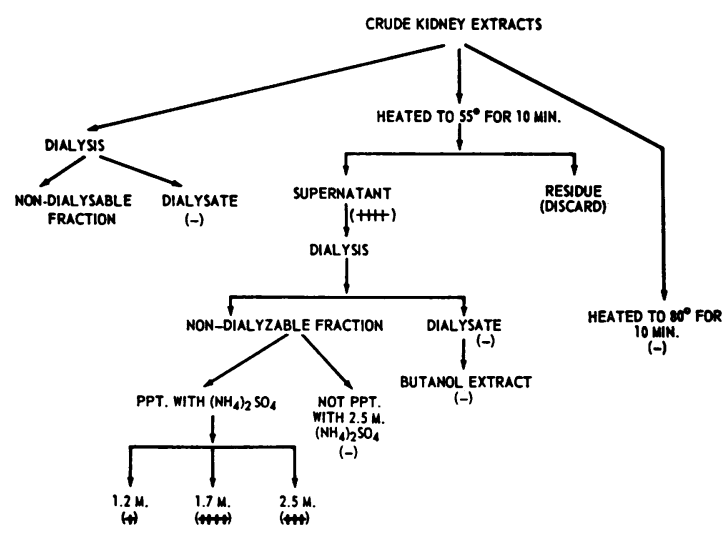

Fig. 1. SCHEME FOR FRACTIONATION OF CRUDE KIDNEY EXTRACTS. No biological activity by assay is indicated by $(-) ;(+)$ and $(++++)$ represent slight biological activity and marked activity, respectively.

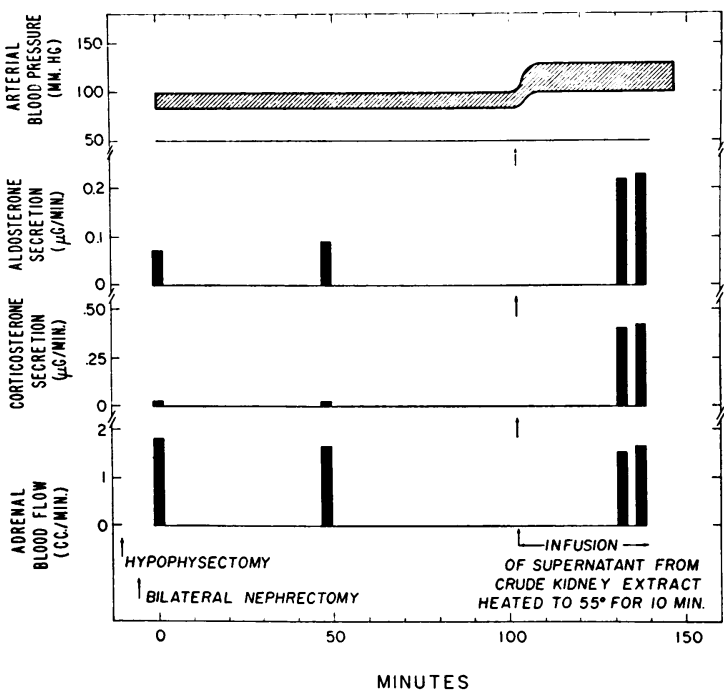

Fig. 2. EfFects of the supernatant from a CRUde KIDNEY EXTRACT (HEATED TO $55^{\circ} \mathrm{C}$ FOR 10 MINUTES) ON STEROID SECRETION AND ARTERIAL PRESSURE.

Extraction and assay of renin. After anesthesia with sodium pentobarbital, the kidneys were removed from 7 normal dogs, 8 dogs with thoracic caval constriction (12), and 2 dogs with cardiac failure $(13,14)$. All animals received a synthetic diet which contained $60 \mathrm{mEq}$ per day of $\mathrm{Na}$ and $18 \mathrm{mEq}$ per day of $\mathrm{K}$. Sodium retention was virtually complete in all experimental animals. Cardiac decompensation was produced by progressive pulmonic stenosis (13) in $1 \mathrm{dog}$, and by a combination of chronic tricuspid insufficiency and pulmonic stenosis (14) in the other animal. The kidneys were immediately placed at $-20^{\circ} \mathrm{C}$ and stored at this temperature for several weeks or months before extraction for renin.

The extraction procedure of Haas and Goldblatt (15) was used with the exception that the extract was acidified to $\mathrm{pH} 2.75$ rather than to $\mathrm{pH}$ 2.6. This modification was adopted after extraction and assay of normal dog kidney showed a maximum yield at $\mathrm{pH} 2.75$. A Beckman expanded scale model $76 \mathrm{pH}$ meter was used. As a control on the extraction procedure, the two kidneys from each normal dog were extracted concurrently with the two kidneys from each dog with caval constriction or heart failure, with the exception of the last 3 dogs' kidneys.

The renin preparations were stored at $-20^{\circ} \mathrm{C}$ for several days before assay. The assay method of Haas and Goldblatt (15) was employed; an increase in arterial pressure was measured in normal, conscious, well trained dogs which lay quietly on a table. Arterial pressure was determined by direct puncture of the femoral artery, with a Statham strain gage and recorded with a Sanborn recording system. Each renin preparation was assayed in 2 or 3 animals.

Measurements of the arterial blood pressure response to angiotensin $I I$. The increase in mean arterial blood 
pressure after a single intravenous injection of synthetic angiotensin II (Ciba) was studied in conscious dogs. Each of 5 normal dogs, 5 dogs with chronic thoracic caval constriction, and $5 \mathrm{Na}$-depleted dogs was studied twice at four dose levels-0.5, 1.0, 2.0, and $4.0 \mu \mathrm{g}$. Sodium depletion was accomplished by feeding a low $\mathrm{Na}$ intake (less than $3 \mathrm{mEq}$ per day of $\mathrm{Na}$ ) for 2 to 3 weeks and by the intramuscular injection of $2 \mathrm{ml}$ of mercuhydrin on at least two occasions. Arterial pressure was measured by the technique used for the renin assays.

Examination of the renal juxtaglomerular cells. The kidneys from 10 normal dogs and from 12 dogs with thoracic caval constriction were studied. All animals received a synthetic diet which contained $60 \mathrm{mEq}$ per day of $\mathrm{Na}$ and $18 \mathrm{mEq}$ per day of $\mathrm{K}$. In the dogs with caval constriction at the time of sacrifice, $\mathrm{Na}$ retention was marked and a large volume of ascites was present. The animals were killed by injection of a large dose of sodium pentobarbital and the kidneys were extirpated immediately.

Kidney slices, 1 to $2 \mathrm{~mm}$ in thickness, were fixed by the Helly technique. The tissue was fixed for 24 hours in a mixture of $5 \mathrm{ml}$ of 40 per cent formalin and $95 \mathrm{ml}$ of Zenker's stock solution without acetic acid. After washing in running tap water for 24 hours, the tissue was transferred to 70 per cent ethanol. The tissue was imbedded, sectioned, and stained by the Bowie technique (16). Histological sections were studied for hypergranulation and hyperplasia of juxtaglomerular cells. The pathologist was not told which tissues were from normal and which from experimental animals. An index of granulation was obtained by counting units of juxtaglomerular cells and weighting each according to degree of granulation from + to +++ . The index is defined as the total number of weighted units per 100 glomeruli (17).

Effects of suprarenal aortic constriction. Fifteen normal dogs were anesthetized lightly with $\mathrm{Na}$ pentobarbital, the anterior pituitary was removed, the right adrenolumbar vein was cannulated, and a loose ligature was placed around the aorta immediately superior to the origin of the renal arteries. Polyethylene catheters were placed in the left subclavian artery and the lower abdominal aorta, and arterial pressures were recorded above and below the aortic ligature throughout the experiment. After control observations on adrenocortical steroid secretion and arterial pressure, the aorta was constricted until a marked reduction in pulse pressure and a substantial fall in mean pressure occurred. Studies were made after this initial aortic constriction and after further, more marked, aortic constriction. Finally, the aortic ligature was loosened and recovery observations were made. There

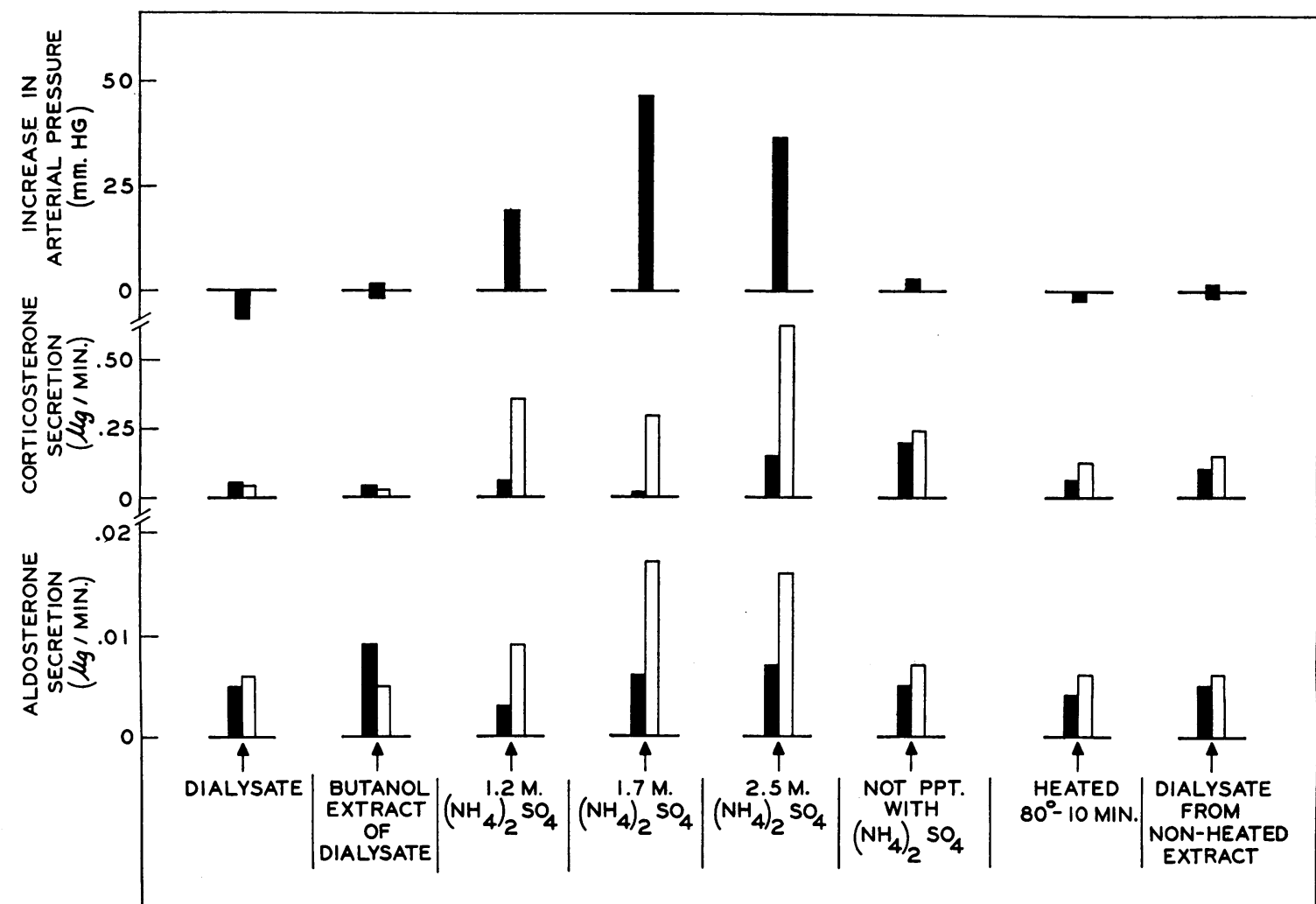

FRACTIONS FROM CRUDE KIDNEY EXTRACTS

Fig. 3. RESUlts FROM ASSAY OF FRACTIONS OF CRUDE KIDNEY EXTRACTS FOR STEROIDOGENIC AND PRESSOR ACTIVITY. 
were 30-minute intervals between periods for collection of adrenal vein blood. The methods for collection of adrenal vein blood, for analysis of the concentrations of aldosterone and corticosterone, and for recording arterial pressure are the same as those described previously (9-11). In five of the animals, the renal clearances of creatinine $(\mathrm{Cr})$ and para-aminohippurate $(\mathrm{PAH})$ were measured throughout the experiment by classical methods. An infusion of $\mathrm{Cr}$ and $\mathrm{PAH}$ in 5 per cent mannitol was given at a rate of $2 \mathrm{ml}$ per minute. There were 30 minute renal clearance periods.

\section{RESULTS}

Fractionation of crude kidney extracts for aldosterone-stimulating and pressor activity. The supernatant from the crude kidney extracts heated to $55^{\circ} \mathrm{C}$ for 10 minutes showed marked aldosterone-stimulating and pressor activity; a typical result is presented in Figure 2. Further fractionation showed that the $1.7 \mathrm{M}$ ammonium sulfate fraction increased aldosterone secretion from 0.006 to $0.017 \mu$ g per minute $(\mathrm{p}<0.01, \mathrm{~N}=7$; see Figures 1 and 3 ). All other fractions failed to show a statistically significant effect on aldosterone production; the standard error (SE) of the difference between the control and experimental values for the $2.5 \mathrm{M}$ fraction was so high (5.03), that $p>0.05$. In three of seven assays of the dialysate from the heated extracts, the assay was unsatisfactory because of a marked depressor response. Corticosterone secretion was increased by both the 1.7 and $2.5 \mathrm{M}$ fractions only ( $\mathrm{p}<0.05$ for both fractions, $\mathrm{N}=7$ ); with the $1.2 \mathrm{M}$ fraction an increase in corticosterone secretion occurred in only three of seven assays, and the increase in the average value from 0.06 to

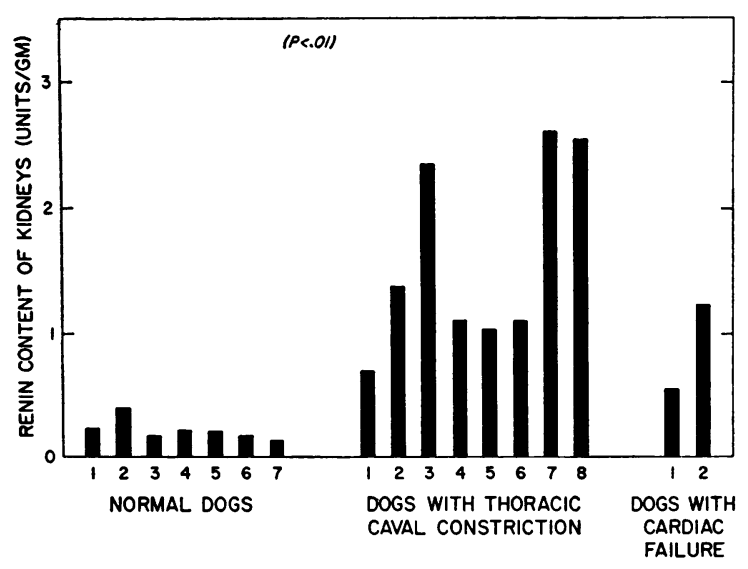

Fig. 4. Renin CONTENT OF DOG KIDNeys.

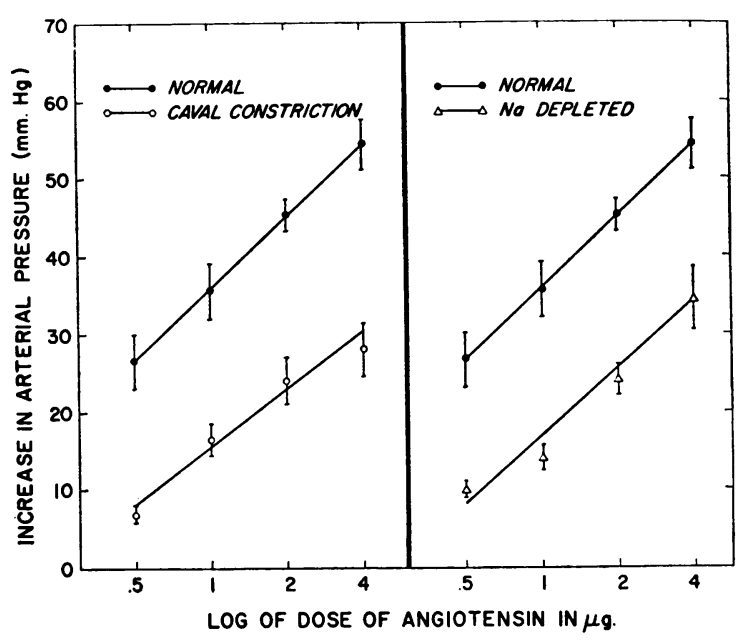

Fig. 5. EFFECTS OF SYNTHETIC ANGIOTENSIN II ON MEAN ARTERIAL BLOOD PRESSURE IN NORMAL DOGS, DOGS WITH THORACIC CAVAL CONSTRICTION, AND NA-DEPLETED DOGS.

0.36 was due to a very marked increase in one assay. The response in Porter-Silber chromogen secretion was measured for the $1.7 \mathrm{M}$ ammonium sulfate fraction only; an increase from 0.06 to $0.30 \mu \mathrm{g}$ per minute occurred $(\mathrm{p}<0.01, \mathrm{~N}=7)$. Arterial pressure increased significantly with the $1.7 \mathrm{M}(\mathrm{p}<0.01, \mathrm{~N}=7)$ and $2.5 \mathrm{M}(\mathrm{p}<0.01$, $\mathrm{N}=7$ ) fractions only; the greater increase occurred with the $1.7 \mathrm{M}$ fraction. The elevation in arterial pressure was sustained throughout the infusion of the fraction. Aldosterone-stimulating activity and the pressor response were closely associated, a finding clearly discernible in individual experiments.

Renin content of kidneys from normal dogs, dogs with thoracic caval constriction, and dogs with cardiac failure. The mean value of the renin content of kidneys from dogs with caval constriction was $1.49 \mathrm{U}^{1}$ per $\mathrm{g}$ of kidney in comparison with an average value of $0.22 \mathrm{U}$ per $\mathrm{g}$ for normal dog kidney $(p<0.01, N=7$; Figure 4$)$. Kidneys from two dogs with cardiac failure showed a renin content higher than that of kidneys from any of the normal dogs.

Effects of angiotensin II on arterial pressure in normal dogs, in dogs with caval constriction, and in sodium-depleted dogs. The response in ar-

${ }^{1} \mathrm{~A}$ unit of renin is defined as the amount which increases the mean arterial blood pressure $30 \mathrm{~mm} \mathrm{Hg}$ in trained, conscious dogs (15). 

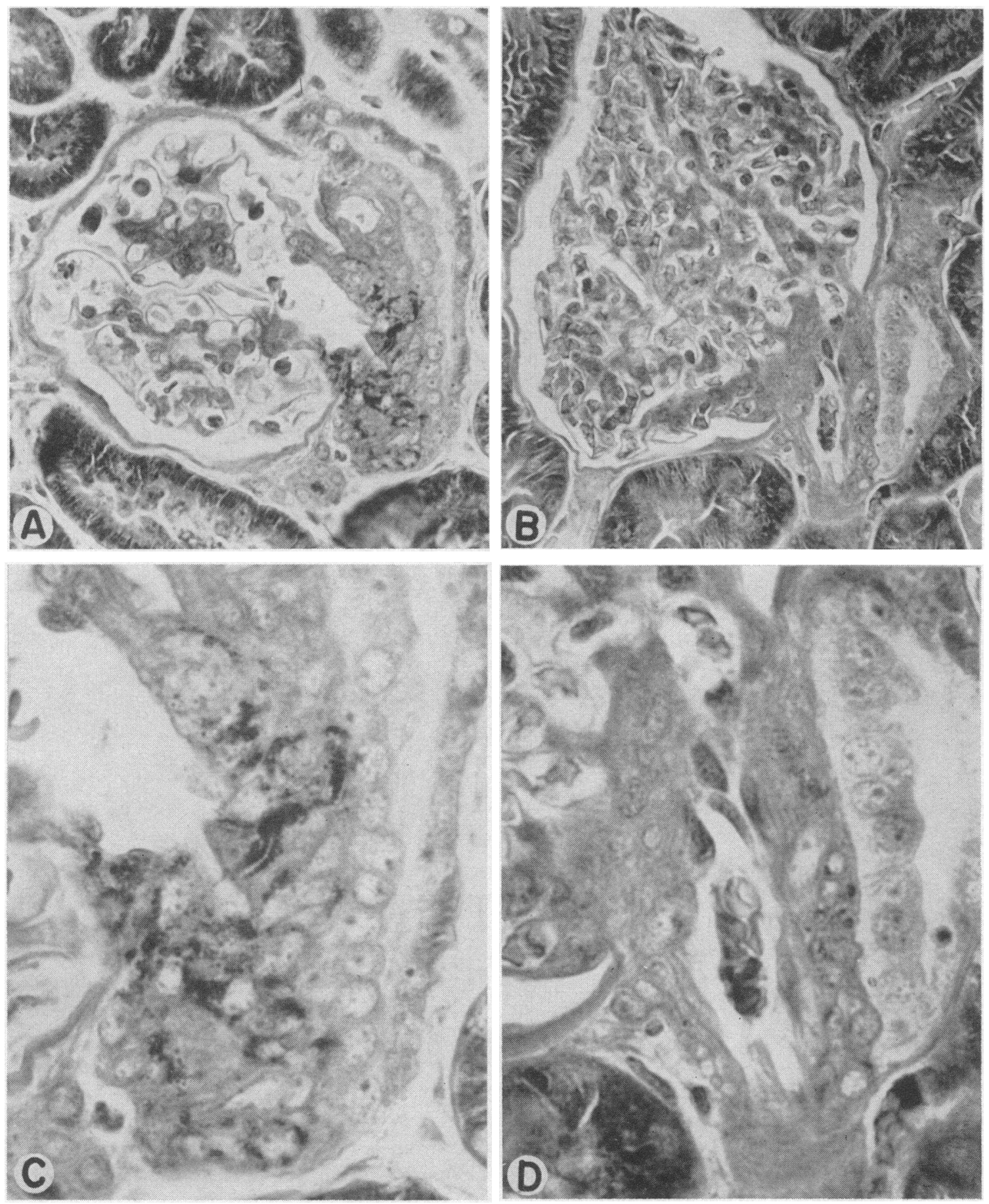

Fig. 6. Paraffin SeCRetions of kidneys Stained BY the Bowie tech NiQue and Photographed With A Wratten G Filter. A. Kidney from a dog with caval construction. A glomerulus occupies most of the field with the afferent arteriole and macula densa at the lower right. Even at this low power $(\times 450)$, granules in juxtaglomerular cells appear prominent. This field is seen at higher magnification $(\times 1,100)$ in Figure C. Note hyperplasia and hypergranulation of juxtaglomerular cells. B. Kidney from a normal dog for comparison with Figure A. At this magnification $(\times 450)$, juxtaglomerular cell granules are barely discernible in the wall of the arteriole at the lower right. This portion of the field is shown at higher magnification $(\times 1,100)$ in Figure $D$. Granules are small and sparse, as is normal for juxtaglomerular cells in this species. 
terial pressure to angiotensin II was markedly reduced at all four dose levels in both groups of experimental animals and the log-dose response was linear over the range of dosages studied (Figure 5$)$. The greatest reduction in response was at the lowest dose level $(0.5 \mu \mathrm{g})$; an increase in arterial pressure of $27 \mathrm{~mm} \mathrm{Hg}$ occurred in the normal dogs, whereas arterial pressure increased only 7 and $10 \mathrm{~mm} \mathrm{Hg}$ for the dogs with caval constriction and the Na-depleted dogs, respectively.

Histopathology of the renal juxtaglomerular cells in dogs with chronic thoracic caval constriction and secondary hyperaldosteronism. There was marked hypergranulation of the juxtaglomerular cells of kidneys from dogs with thoracic caval constriction (Figures 6 and 7 ). The average juxtaglomerular index for the 12 dogs with caval constriction was 31.0 , compared with an index of 12.9 for the 10 normal $\operatorname{dogs}(p<0.01)$. In the kidneys from the dogs with caval constriction in which the degree of granulation was most marked, there was also hyperplasia of the juxtaglomerular cells (Figure 6).

Acute effects of suprarenal aortic constriction on steroid secretion, aortic pressure, and renal blood flow. Constriction of the aorta resulted in a drop in arterial pressure below the site of narrowing and presumably in the renal arteries (Table I and Figure 8). Each immediate drop in pressure after constriction was followed by a progressive increase in pressure which necessitated repeated constriction of the aorta (see Figure 8 ). The values for arterial pressure to the left and to the right of the diagonal lines in Table

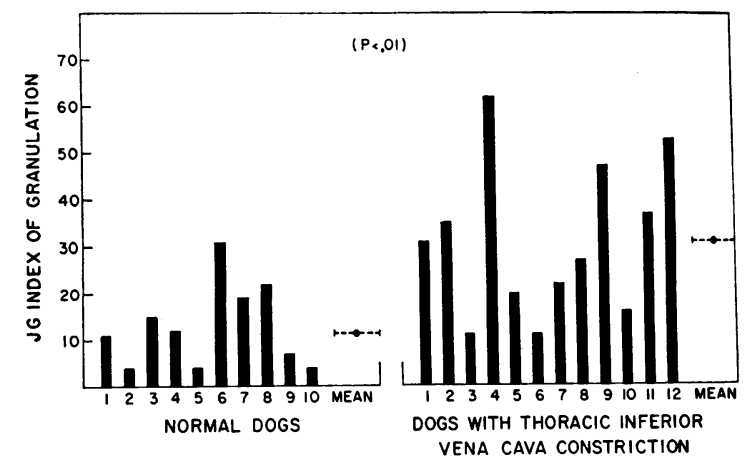

Fig. 7. Degree of granulation of the juXtagloMERULAR (JG) CELLS (JG INDEX OF GRANULATION) IN NORMAL DOGS AND IN DOGS WITH CAVAL CONSTRICTION.

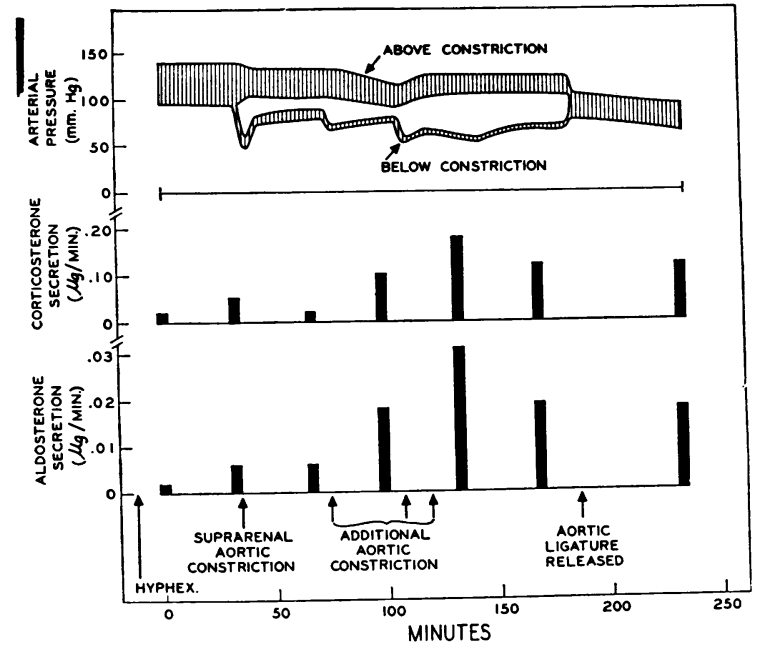

Fig. 8. EFFEcts of CONStriction of the Aorta ABove THE RENAL ARTERIES ON ARTERIAL PRESSURE AND STEROID SECRETION.

I represent pressures above and below the constriction, respectively. Measurements of effective renal plasma flow and glomerular filtration rate in 5 of the 15 dogs showed a reduction in both functions in all experiments (Table I). The hematocrit was unchanged after constriction in most experiments. The drop in renal blood flow was consistently greater than the fall in aortic pressure and, consequently, renal resistance was increased. Aldosterone secretion increased in 9 of the 15 dogs (Table I and Figure 8); comparison of the average control value with the average of the two highest experimental values shows a statistically significant elevation in aldosterone production for the entire group of 15 $\operatorname{dogs}(p<0.01)$. In all seven of the experiments with recovery observations in which aldosterone secretion increased (nos. 3, 5, 8, 9, 11, 13 . and 15), aldosterone production was lower during the recovery period. Corticosterone secretion was also frequently increased during aortic constriction and the average increase for the group was from 0.08 to $0.21 \mu \mathrm{g}$ per minute $(\mathrm{p}<0.05$. $\mathrm{N}=15$; Table I and Figure 8). Adrenal blood flow did not vary appreciably during the observations except in experiment 2 in which a 50 per cent reduction occurred after aortic constriction. Comparison of the findings in six experiments (nos. 2, 4, 6, 10, 12, and 14) in which aldosterone secretion failed to increase, with the results in the 
TABLE I

Effects of acute constriction of the aorta above the renal arteries on steroid secretion, aortic pressure, and renal blood flow in hypophysectomized dogs*

\begin{tabular}{|c|c|c|c|c|c|c|c|}
\hline \multirow{2}{*}{$\begin{array}{l}\text { Experi- } \\
\text { ment } \\
\text { no. }\end{array}$} & & \multicolumn{2}{|c|}{ Control periods } & \multicolumn{3}{|c|}{ Periods during aortic constriction } & \multirow{2}{*}{$\begin{array}{c}\text { Recovery } \\
\text { period }\end{array}$} \\
\hline & & 1 & 2 & 1 & 2 & 3 & \\
\hline \multirow[t]{3}{*}{1} & \multirow{2}{*}{$\begin{array}{l}\text { Aldosterone } \\
\text { Corticosterone } \\
\text { Arterial } \\
\text { pressure }\end{array}$} & 0.010 & $\begin{array}{l}0.011 \\
0.02\end{array}$ & 0.027 & 0.020 & & \\
\hline & & & $125 / 125$ & $105 / 65$ & $100 / 60$ & & \\
\hline & \multirow{4}{*}{$\begin{array}{l}\text { Aldosterone } \\
\text { Corticosterone } \\
\text { Arterial } \\
\text { pressure }\end{array}$} & & & & & & \\
\hline \multirow[t]{3}{*}{2} & & 0.004 & 0.006 & 0.006 & 0.006 & & \\
\hline & & 0.03 & 0.41 & 0.11 & 0.63 & & \\
\hline & & $75 / 75$ & $75 / 75$ & $70 / 42$ & $77 / 50$ & & \\
\hline \multirow[t]{3}{*}{3} & \multirow{3}{*}{$\begin{array}{l}\text { Aldosterone } \\
\text { Corticosterone } \\
\text { Arterial } \\
\text { pressure }\end{array}$} & 0.002 & 0.006 & 0.049 & 0.052 & 0.019 & 0.010 \\
\hline & & 0.06 & 0.06 & 0.03 & 0.04 & 0.15 & 0.06 \\
\hline & & $100 / 100$ & $102 / 102$ & $113 / 94$ & $120 / 78$ & $128 / 48$ & $124 / 124$ \\
\hline \multirow[t]{2}{*}{4} & \multirow{2}{*}{$\begin{array}{l}\text { Aldosterone } \\
\text { Corticosterone } \\
\text { Arterial } \\
\text { pressure }\end{array}$} & $\begin{array}{l}0.020 \\
0.08\end{array}$ & $\begin{array}{l}0.016 \\
0.11\end{array}$ & $\begin{array}{l}0.015 \\
0.12\end{array}$ & $\begin{array}{l}0.013 \\
0.08\end{array}$ & & \\
\hline & & $100 / 100$ & $75 / 75$ & $96 / 57$ & $110 / 68$ & & \\
\hline \multirow[t]{3}{*}{5} & \multirow{3}{*}{$\begin{array}{l}\text { Aldosterone } \\
\text { Corticosterone } \\
\text { Arterial } \\
\text { pressure }\end{array}$} & 0.002 & 0.006 & 0.018 & 0.031 & 0.021 & 0.018 \\
\hline & & 0.02 & 0.05 & 0.10 & 0.18 & 0.12 & 0.12 \\
\hline & & $110 / 110$ & $110 / 110$ & $110 / 77$ & $115 / 56$ & $115 / 65$ & $95 / 95$ \\
\hline \multirow[t]{2}{*}{6} & \multirow{2}{*}{$\begin{array}{l}\text { Aldosterone } \\
\text { Corticosterone } \\
\text { Arterial } \\
\text { pressure }\end{array}$} & $\begin{array}{l}0.006 \\
0.02\end{array}$ & $\begin{array}{l}0.007 \\
0.05\end{array}$ & $\begin{array}{l}0.008 \\
0.16\end{array}$ & $\begin{array}{l}0.008 \\
0.15\end{array}$ & $\begin{array}{l}0.008 \\
0.09\end{array}$ & $\begin{array}{l}0.008 \\
0.07\end{array}$ \\
\hline & & $130 / 130$ & $137 / 137$ & $140 / 70$ & $140 / 70$ & $146 / 70$ & $135 / 135$ \\
\hline \multirow[t]{3}{*}{7} & \multirow{3}{*}{$\begin{array}{l}\text { Aldosterone } \\
\text { Corticosterone } \\
\text { Arterial } \\
\text { pressure }\end{array}$} & 0.004 & 0.003 & 0.007 & 0.014 & 0.009 & \\
\hline & & 0.05 & 0.07 & 0.16 & 0.11 & 0.13 & \\
\hline & & $82 / 82$ & $90 / 90$ & $108 / 95$ & $115 / 74$ & $115 / 74$ & \\
\hline \multirow[t]{2}{*}{8} & \multirow{2}{*}{$\begin{array}{l}\text { Aldosterone } \\
\text { Corticosterone } \\
\text { Arterial } \\
\text { pressure }\end{array}$} & $\begin{array}{l}0.013 \\
0.01\end{array}$ & $\begin{array}{l}0.025 \\
0.02\end{array}$ & $\begin{array}{l}0.028 \\
0.03\end{array}$ & $\begin{array}{l}0.036 \\
0.06\end{array}$ & $\begin{array}{l}0.041 \\
0.06\end{array}$ & $\begin{array}{l}0.038 \\
0.05\end{array}$ \\
\hline & & $103 / 103$ & $107 / 107$ & $110 / 90$ & $115 / 67$ & $115 / 67$ & $93 / 93$ \\
\hline \multirow[t]{3}{*}{9} & \multirow{3}{*}{$\begin{array}{l}\text { Aldosterone } \\
\text { Corticosterone } \\
\text { Arterial } \\
\text { pressure } \\
\text { C }_{\text {Cr }} \\
\text { C }_{\text {PAH }}\end{array}$} & 0.007 & 0.009 & 0.012 & 0.018 & 0.015 & 0.005 \\
\hline & & 0.04 & 0.08 & 0.13 & 0.13 & 0.14 & 0.04 \\
\hline & & $\begin{array}{c}103 / 103 \\
36 \\
57\end{array}$ & $\begin{array}{c}105 / 105 \\
33 \\
71\end{array}$ & $\begin{array}{c}75 / 55 \\
17 \\
21\end{array}$ & $\begin{array}{c}82 / 30 \\
3 \\
3\end{array}$ & $87 / 42$ & $60 / 60$ \\
\hline \multirow[t]{2}{*}{10} & \multirow{2}{*}{$\begin{array}{l}\text { Aldosterone } \\
\text { Corticosterone } \\
\text { Arterial } \\
\text { pressure } \\
\text { C }_{\text {Cr }} \\
\text { C }_{\text {PAB }}\end{array}$} & $\begin{array}{l}0.004 \\
0.14\end{array}$ & $\begin{array}{l}0.002 \\
0.14\end{array}$ & $\begin{array}{l}0.006 \\
0.17\end{array}$ & $\begin{array}{l}0.004 \\
0.16\end{array}$ & $\begin{array}{l}0.005 \\
0.16\end{array}$ & $\begin{array}{l}0.008 \\
0.13\end{array}$ \\
\hline & & $\begin{array}{c}155 / 155 \\
65 \\
182\end{array}$ & $\begin{array}{c}130 / 130 \\
64 \\
147\end{array}$ & $\begin{array}{c}130 / 118 \\
56 \\
130\end{array}$ & $\begin{array}{c}130 / 110 \\
27 \\
82\end{array}$ & $133 / 110$ & $\begin{array}{c}120 / 120 \\
38 \\
137\end{array}$ \\
\hline \multirow[t]{2}{*}{11} & \multirow{2}{*}{$\begin{array}{l}\text { Aldosterone } \\
\text { Corticosterone } \\
\text { Arterial } \\
\text { pressure } \\
\text { C }_{\text {Cr }} \\
\text { C }_{\text {PAH }}\end{array}$} & $\begin{array}{l}0.014 \\
0.81\end{array}$ & $\begin{array}{l}0.014 \\
0.51\end{array}$ & $\begin{array}{l}0.012 \\
0.57\end{array}$ & $\begin{array}{l}0.018 \\
0.54\end{array}$ & $\begin{array}{l}0.024 \\
0.58\end{array}$ & $\begin{array}{l}0.012 \\
0.45\end{array}$ \\
\hline & & $\begin{array}{c}118 / 120 \\
50 \\
197\end{array}$ & $\begin{array}{c}130 / 130 \\
43 \\
162\end{array}$ & $\begin{array}{c}132 / 100 \\
14 \\
64\end{array}$ & $\begin{array}{c}126 / 70 \\
9 \\
36\end{array}$ & $126 / 70$ & $\begin{array}{c}107 / 110 \\
16 \\
58\end{array}$ \\
\hline
\end{tabular}

* The rates of aldosterone and corticosterone secretion are expressed in $\mu \mathrm{g} / \mathrm{min}$. Mean arterial pressures above and below the constriction are presented to the left and to the right, respectively, of the diagonal lines. $\mathrm{C}_{\mathrm{Gr}}$ and $\mathrm{C}_{\mathrm{PAB}}$ are the renal plasma clearances in $\mathrm{ml} / \mathrm{min}$ of creatinine and para-aminohippurate. The interval between periods for collection of adrenal vein blood was approximately 30 minutes. 


\begin{tabular}{|c|c|c|c|c|c|c|c|}
\hline \multirow{2}{*}{$\begin{array}{c}\text { Experi- } \\
\text { ment } \\
\text { no. }\end{array}$} & & \multicolumn{2}{|c|}{ Control periods } & \multicolumn{3}{|c|}{ Periods during aortic constriction } & \multirow{2}{*}{$\begin{array}{l}\text { Recovery } \\
\text { period }\end{array}$} \\
\hline & & 1 & 2 & 1 & 2 & 3 & \\
\hline \multirow[t]{4}{*}{12} & \multirow{4}{*}{$\begin{array}{l}\text { Aldosterone } \\
\text { Corticosterone } \\
\text { Arterial } \\
\text { pressure } \\
\text { C }_{\text {Cr }} \\
\text { C }_{\mathbf{P A H}}\end{array}$} & 0.005 & 0.007 & 0.008 & 0.005 & 0.004 & 0.002 \\
\hline & & 0.06 & 0.10 & 0.10 & 0.08 & 0.16 & 0.01 \\
\hline & & $90 / 92$ & $85 / 86$ & $110 / 70$ & $120 / 68$ & $120 / 68$ & $85 / 80$ \\
\hline & & $\begin{array}{r}47 \\
118\end{array}$ & $\begin{array}{r}43 \\
107\end{array}$ & $\begin{array}{r}8 \\
58\end{array}$ & $\begin{array}{l}11 \\
69\end{array}$ & & $\begin{array}{l}16 \\
67\end{array}$ \\
\hline \multirow[t]{3}{*}{13} & \multirow{3}{*}{$\begin{array}{l}\text { Aldosterone } \\
\text { Corticosterone } \\
\text { Arterial } \\
\text { pressure }\end{array}$} & 0.000 & 0.004 & 0.009 & 0.008 & & 0.005 \\
\hline & & 0.09 & 0.16 & 0.22 & 0.25 & & 0.13 \\
\hline & & $135 / 132$ & $120 / 120$ & $80 / 60$ & $120 / 85 \dagger$ & & $65 / 55$ \\
\hline \multirow[t]{3}{*}{14} & \multirow{3}{*}{$\begin{array}{l}\text { Aldosterone } \\
\text { Corticosterone } \\
\text { Arterial } \\
\text { pressure } \\
\text { C }_{\text {Cr }} \\
\text { C }_{\mathrm{PAH}}\end{array}$} & 0.000 & 0.000 & & 0.001 & & 0.001 \\
\hline & & 0.05 & 0.04 & 0.120 & 0.064 & & 0.102 \\
\hline & & $\begin{array}{c}83 / 85 \\
70 \\
236\end{array}$ & $\begin{array}{c}83 / 85 \\
70 \\
254\end{array}$ & $\begin{array}{c}76 / 34 \\
23 \\
85\end{array}$ & $\begin{array}{c}76 / 34 \\
4 \\
8\end{array}$ & & $\begin{array}{c}65 / 65 \\
26 \\
156\end{array}$ \\
\hline \multirow[t]{8}{*}{15} & \multirow{3}{*}{$\begin{array}{l}\text { Aldosterone } \\
\text { Corticosterone } \\
\text { Arterial } \\
\text { pressure }\end{array}$} & 0.011 & 0.015 & 0.037 & 0.029 & & 0.019 \\
\hline & & 0.16 & 0.13 & 0.24 & 0.13 & & 0.04 \\
\hline & & $95 / 95$ & $90 / 90$ & $115 / 80$ & $105 / 85$ & & $85 / 85$ \\
\hline & \multirow{5}{*}{$\begin{array}{l}\text { Mean values: } \\
\text { Aldosterone } \\
\text { Corticosterone } \\
\text { Arterial } \\
\text { pressure } \\
\text { C }_{\mathrm{Cr}} \\
\mathrm{C}_{\mathrm{PAH}}\end{array}$} & & & & & & \\
\hline & & $\begin{array}{l}0.007 \\
0.06\end{array}$ & $\begin{array}{l}0.009 \\
0.10\end{array}$ & $\begin{array}{l}0.017 \\
0.20\end{array}$ & $\begin{array}{l}0.018 \\
0.21\end{array}$ & $\begin{array}{l}0.016 \\
0.13\end{array}$ & $\begin{array}{l}0.011 \\
0.11\end{array}$ \\
\hline & & & & & & & \\
\hline & & $\begin{array}{c}107 / 107 \\
54\end{array}$ & $\begin{array}{c}104 / 104 \\
51\end{array}$ & $\begin{array}{c}105 / 74 \\
24\end{array}$ & $\begin{array}{c}110 / 67 \\
11\end{array}$ & $121 / 68$ & $\begin{array}{c}94 / 93 \\
24\end{array}$ \\
\hline & & 158 & 148 & 72 & 40 & & 105 \\
\hline
\end{tabular}

† A norepinephrine infusion was given to maintain adrenal blood flow at the control level.

other nine experiments in which an elevation in aldosterone production occurred, failed to reveal a difference which would consistently explain the divergent responses of the two groups.

\section{DISCUSSION}

There is a large body of evidence $(1-8,17-21)$ to suggest that the renin-angiotensin system is important in the physiologic control of aldosterone secretion. Also, the primary mechanism for hypersecretion of aldosterone during experimental ascites formation appears to be mediated by the renin-angiotensin system (4). One of the first indications (1) that the kidney secretes an ASH which is a prime regulator of aldosterone secretion was the finding that aldosterone production fell after nephrectomy of hypophysectomized dogs. During this study (1) it was also observed that nephrectomized-hypophysectomized dogs failed to show an increase in aldosterone secretion after acute hemorrhage. In contrast, each of two series of simple hypophysectomized dogs gave a 100 per cent increase in aldosterone secretion in response to acute blood loss. Intravenous injection of crude saline extracts of kidneys from normal dogs resulted in a striking elevation in aldosterone secretion. The physiologic importance of a renal ASH was demonstrated by the finding (4) that aldosterone secretion fell markedly after acute bilateral nephrectomy of hypophysectomized, Na-depleted dogs. Alterations in $\mathrm{Na}$ intake constitute one of the most important mechanisms for regulation of the daily rate of aldosterone secretion, and the finding that an ASH is secreted by the kidney in response to chronic $\mathrm{Na}$ depletion (4) serves to emphasize the physiologic role of the hormone. The secretion of an ASH in experimental states with hyperaldosteronism and chronic $\mathrm{Na}$ retention was demonstrated by the observations that:1) acute nephrectomy of hypophysectomized caval dogs resulted in a marked fall in aldosterone secretion; and 2) crude saline extracts of kidney from these animals restored aldosterone production. This evidence 
that the kidney secretes an ASH, and the reports that renin injections lead to hypertrophy of the zona glomerulosa $(18,22)$ and that the amount of extractable renin was correlated with the width of the zona glomerulosa (22), strongly suggest the possibility that ASH is renin. Also, it is well known (6-8) that angiotensin II is a potent stimulator of aldosterone secretion.

To provide more conclusive evidence for the chemical nature of this ASH, in the present study crude kidney extracts were systematically fractionated. The various fractions were assayed for both steroidogenic and pressor activity simultaneously to test the possibility that ASH is renin. It has been demonstrated previously (6) that renin preparations made by precipitation of crude kidney extracts with $2.2 \mathrm{M}$ ammonium sulfate showed aldosterone-, corticosterone-, and cortisolstimulating activity, as well as an increase in arterial pressure.

The present data show that marked steroidogenic and pressor activity was retained after heating crude kidney extracts to $55^{\circ} \mathrm{C}$ for 10 minutes. Assay of the dialysate from the supernatant of heated extracts and assay of butanol extracts of the dialysate from the same material showed no activity. This findings suggests that the aldosterone-stimulating and pressor activity in the supernatant was due to molecules too large to diffuse through the cellophane; the possibility, however, that a small active molecule was bound to protein is not excluded. Butanol is an excellent solvent for large polypeptide molecules and failure of the butanol extracts to increase aldosterone secretion provides additional evidence that $\mathrm{ASH}$ is not a polypeptide. The nondialyzable protein was further fractionated with ammonium sulfate; the $1.7 \mathrm{M}$ fraction was the only one to produce a statistically significant increase in aldosterone secretion. However, both the 1.7 and $2.5 \mathrm{M}$ fractions increased corticosterone production and arterial pressure. It should be emphasized that an increase in aldosterone-stimulating activity and a pressor response were always closely associated; this relationship was sufficiently striking to be discernible even from individual assays. Since 1.7 and $2.5 \mathrm{M}$ ammonium sulfate is known to precipitate renin, the present data suggest that the active agent in the nondialyzable protein fraction was renin. Heating of renin to $80^{\circ} \mathrm{C}$ for 10 minutes destroys the hormone (23), so the present finding that both aldosterone-stimulating and pressor activity were absent after heat provides additional evidence that ASH is renin. Finally, failure of the dialysate from nonheated kidney extracts to show biological activity indicates that ASH is not a small molecule such as a polypeptide which might have been destroyed by heat. These fractionation studies provide strong evidence that the ASH present in crude kidney extracts is renin.

Since there is evidence that ASH is renin and renin appears to be secreted at an increased rate by the kidney in dogs with experimental secondary hyperaldosteronism produced by caval constriction (4), the renin content of kidneys from these experimental animals was measured. The present data demonstrate that the renin content of kidneys from dogs with caval constriction was sevenfold greater than the renin content of normal dog kidneys. Also, kidneys from two dogs with experimental congestive heart failure showed a higher renin content than normal dog kidneys. These findings are consistent with an earlier report (6) that a high renin content of the kidney is associated with hypersecretion of aldosterone. In experimental renal hypertension produced by renal artery constriction (6), hyperaldosteronism and a high renin content in the kidney (tenfold increase) were consistently present in dogs with a malignant syndrome, whereas in benign experimental renal hypertension aldosterone secretion was normal and the renin content of the kidneys was only doubled. Also, during chronic $\mathrm{Na}$ depletion, which is associated with hypersecretion of aldosterone, the renin content of the kidney is increased $(20,24,25)$. Finally, in patients with congestive heart failure, Merrill, Morrison and Brannon (26) found an augmented rate of secretion of renin by the kidney. This indirect evidence for increased renin secretion in experimental states with hyperaldosteronism and the direct demonstration of hypersecretion of renin in patients with heart failure provide convincing support for the concept that ASH is renin.

The evidence for increased secretion of renin in dogs with caval constriction, in $\mathrm{Na}$-depleted dogs, and in patients with congestive failure suggests that the peripheral plasma level of angiotensin II is elevated. What, then, is the explana- 
tion for the absence of hypertension in experimental and clinical states with hyperaldosteronism secondary to hyperangiotensinemia? One possible explanation is that increased angiotensin II maintains a normal or near normal arterial pressure which would otherwise be low. In patients with congestive heart failure of the low output type, increased circulating angiotensin II may provide an important compensatory mechanism to maintain a relatively normal arterial pressure by a direct action on the peripheral arterioles to increase peripheral resistance. In the present study, the decreased response to angiotensin II in dogs with caval constriction and in Na-depleted dogs may reflect a state of increased peripheral arteriolar constriction secondary to a high plasma level of angiotensin II. Thus, the renin-angiotensin system may provide a homeostatic mechanism to maintain an adequate flow of blood to vital organs by effecting vasoconstriction in less vital areas. Also, a high circulating level of aldosterone which seems to be secondary to a high plasma level of angiotensin II $(1,6,24)$ plays a role in homeostasis by conservation of salt and water and maintenance of circulating blood volume. The renin-angiotensin system appears, therefore, to constitute one of the most important mechanisms for the maintenance of a normal blood volume, arterial pressure, and blood flow through vital organs.

The close association of the degree of granulation of the renal juxtaglomerular cells with the renin content of the kidney in several experimental situations $(20-22,24,25)$ has led to the suggestion that renin is secreted by these cells. The present data demonstrate the presence of hypergranulation and hyperplasia of the renal juxtaglomerular cells in association with a high renin content of the kidney in dogs with hyperaldosteronism secondary to thoracic caval constriction. This triad of findings has also been reported during chronic $\mathrm{Na}$ depletion $(4,20)$. Of further interest is the earlier observation (4) that acute bilateral nephrectomy markedly reduced the rates of aldosterone and corticosterone secretion in hypophysectomized caval and hypophysectomized Na-depleted dogs. Also, after acute hemorrhage, there is evidence for release of renin by the kidney (27), and increased aldosterone production occurs (1-3). The most reasonable interpretation of available data is that in all three experimental situations (caval constriction, $\mathrm{Na}$ depletion, and acute blood loss), renin is secreted by the juxtaglomerular cells and that angiotensin II regulates aldosterone secretion. The striking similarity of the response to caval constriction, chronic sodium depletion, and acute blood loss, as measured by a) granulation of juxtaglomerular cells, $b$ ) renin content of the kidney or renin secretion of the kidney, and $c$ ) aldosterone production, suggests that all three experimental conditions may involve identical stimuli.

The stimuli resulting from chronic caval constriction, chronic $\mathrm{Na}$ depletion, and acute hemorrhage seem to be transmitted to the juxtaglomerular cells of the kidney for release of renin. Consequently the renal afferent arterioles constitute a likely site for the receptors, since the juxtaglomerular cells are located in the media of the renal afferent arterioles. In view of the increase in aldosterone secretion in hypophysectomized dogs in response to acute hemorrhage (1-3) and the frequently associated decrease in renal arterial pressure and renal blood flow, the effects of suprarenal aortic constriction on steroid secretion were studied as another method of decreasing the arterial pressure and blood flow in the kidney. The present experiments show an increase in aldosterone and corticosterone production during aortic constriction.

It is of interest that corticosterone as well as aldosterone production was increased following aortic constriction. It has been demonstrated previously (6) that the very smallest doses of angiotensin II which augmented aldosterone production also increased corticosterone secretion. Although the rate of corticosterone output achieved during aortic constriction was significantly higher than the control level, the absolute level during constriction was relatively very low in comparison with that observed in response to the stress of laparotomy in a dog with the pituitary present.

Comparison of the response in aldosterone and corticosterone secretion during aortic constriction to that after hemorrhage in hypophysectomized dogs showed an identical response. After acute hemorrhage in hypophysectomized dogs (1), aldosterone production increased from 0.008 to $0.016 \mu \mathrm{g}$ per minute and corticosterone output in- 
creased from 0.10 to $0.25 \mu \mathrm{g}$ per minute $(\mathrm{N}=$ 16). Also, the finding of a slight increase in corticosterone secretion during aortic constriction is consistent with the earlier observation (4) that corticosterone output fell after acute nephrectomy of hypophysectomized caval and hypophysectomized Na-depleted dogs. Finally, comparison of the rate of corticosterone production in 16 simple hypophysectomized dogs (0.05 $\mu \mathrm{g}$ per minute) (1) with that in 15 hypophysectomized caval or hypophysectomized Na-depleted dogs $(0.14 \mu \mathrm{g}$ per minute) (4) showed a significantly higher value in the group of caval and Na-depleted animals $(t=3.90, \mathrm{p}<0.01)$. These findings on corticosterone secretion indicate that the reninangiotensin system acts at an early stage in the biogenesis of the adrenocortical steroids to promote the synthesis of both corticosterone and aldosterone. The slight increase in corticosterone secretion which occurs in response to caval constriction and to $\mathrm{Na}$ depletion is probably of no physiological importance.

During aortic constriction, a reduction in arterial pressure and renal blood flow occurred and aldosterone secretion increased. The drop in renal blood flow was usually greater than the fall in arterial pressure so that renal resistance was increased. A plausible explanation for the nature of the stimulus is that a decrease in renal arterial pressure and in renal blood flow leads to decreased stretch of the renal afferent arterioles, as suggested by Tobian (24); as a consequence, renin is released by the juxtaglomerular cells. Increased secretion of renin results in an increase in circulating angiotensin II which acts directly on the zona glomerulosa to promote aldosterone secretion. This concept of the renal release of an ASH (renin?) is supported by the consistent finding of a low arterial pressure and renal blood flow at the onset of experimental congestive heart failure of the low output type (13). In experimental high output failure secondary to anemia (28), in which the rates of glomerular filtration and renal plasma flow were usually elevated, renal blood flow (very low hematocrits were present) and arterial pressure were consistently reduced.

\section{SUM MARY}

1. Crude saline extracts of dog kidney were fractionated by heat, dialysis, and ammonium sul- fate precipitation for aldosterone-stimulating and pressor activity. The 1.7 and $2.5 \mathrm{M}$ ammonium sulfate fractions, which are known to precipitate renin, were the only fractions with appreciable steroidogenic activity and only the $1.7 \mathrm{M}$ fraction gave a statistically significant increase in aldosterone secretion. Pressor activity was closely associated with aldosterone-stimulating activity. Heating to $80^{\circ} \mathrm{C}$ for 10 minutes destroyed all aldosterone-stimulating and pressor activity. The data provide strong suggestive evidence that the active agent in crude kidney extracts is renin.

2. Extraction and assay of kidney tissue for renin showed a sevenfold greater renin content of kidneys from dogs with thoracic caval constriction than from normal dog kidneys.

3. The response in arterial pressure to an intravenous injection of synthetic angiotensin II was markedly reduced in dogs with thoracic caval constriction and in Na-depleted dogs in comparison with the effect in normal dogs.

4. The renal juxtaglomerular cells were hypergranulated and hyperplastic in dogs with thoracic caval constriction.

5. Suprarenal aortic constriction of hypophysectomized dogs resulted in a 100 per cent increase in aldosterone secretion and a 150 per cent increase in corticosterone production. The steroidogenic response was associated with a drop in renal arterial pressure and renal blood flow, but renal vascular resistance increased.

6. The findings in the present study support the view that the stimulus associated with a decrease in arterial pressure and blood flow in the kidney leads to secretion of renin by the juxtaglomerular cells. Renin via the formation of angiotensin II and the direct action of angiotensin II on the zona glomerulosa augments aldosterone secretion.

\section{ACKNOWLEDGMENTS}

We are grateful to Dr. Robert Gaunt of Ciba Pharmaceuticals, Summit, N. J., for the synthetic angiotensin II and to Dr. Albert Wettstein of Ciba, Ltd. in Basel, Switzerland, for synthetic aldosterone used in the double isotope assay for aldosterone.

\section{REFERENCES}

1. Davis, J. O., Carpenter, C. C. J., Ayers, C. R., Holman, J. E., and Bahn, R., C. Evidence for secretion of an aldosterone-stimulating hormone by the kidney. J. clin. Invest. 1961, 40, 684. 
2. Davis, J. O. Mechanisms regulating the secretion and metabolism of aldosterone in experimental secondary hyperaldosteronism. Recent Progr. Hormone Res. 1961, 17, 293.

3. Ganong, W. F., and Mulrow, P. J. Evidence of secretion of an aldosterone-stimulating substance by the kidney. Nature (Lond.) 1961, 190, 1115.

4. Davis, J. O., Ayers, C. R., and Carpenter, C. C. J. Renal origin of an aldosterone-stimulating hormone in dogs with thoracic caval constriction and in sodium-depleted dogs. J. clin. Invest. 1961, 41, 1466.

5. Davis, J. O., Titus, E. O., Ayers, C. R., Spiegel, H. E., and Carpenter, C. C. J. Fractionation of crude kidney extracts for aldosterone stimulating activity. Endocr. Soc. Abstracts, 1961, p. 13.

6. Carpenter, C. C. J., Davis, J. O., and Ayers, C. R. Relation of renin, angiotensin II, and experimental renal hypertension to aldosterone secretion. $\mathrm{J}$. clin. Invest. 1961, 40, 2026.

7. Biron, P., Koiw, E., Nowaczynski, W., Brouillet, J., and Genest, J. The effects of intravenous infusions of valine-5 angiotensin II and other pressor agents on urinary electrolytes and corticosteroids, including aldosterone. J. clin. Invest. 1961, 40, 338.

8. Laragh, J. H., Angers, M., Kelly, W. G., and Lieberman, S. Hypotensive agents and pressor substances. The effect of epinephrine, norepinephrine, angiotensin II, and others on the secretory rate of aldosterone in man. J. Amer. med. Ass. 1960, 174, 234.

9. Davis, J. O., Pechet, M. M., Ball, W. C., Jr., and Goodkind, M. J. Increased aldosterone secretion in dogs with right-sided congestive heart failure and in dogs with thoracic inferior vena cava constriction. J. clin. Invest. 1957, 36, 689.

10. Yankopoulos, N. A., Davis, J. O., Kliman, B., and Peterson, R. E. Evidence that a humoral agent stimulates the adrenal cortex to secrete aldosterone in experimental secondary hyperaldosteronism. J. clin. Invest. 1959, 38, 1278.

11. Kliman, B., and Peterson, R. E. Double isotope derivative assay of aldosterone in biological extracts. J. biol. Chem. 1960, 235, 1639.

12. Davis, J. O., and Howell, D. S. Mechanisms of fluid and electrolyte retention in experimental preparations in dogs. II. With thoracic inferior vena cava constriction. Circulat. Res. 1953, 1, 171.

13. Davis, J. O., Hyatt, R. E., and Howell, D. S. Rightsided congestive heart failure in dogs produced by controlled progressive constriction of the pulmonary artery. Circulat. Res. 1955, 3, 252.

14. Yankopoulos, N. A., Davis, J. O., McFarland, J. A., and Holman, J. Physiologic changes during chronic congestive heart failure in dogs with tri- cuspid insufficiency and pulmonic stenosis. Circulat. Res. 1959, 7, 950.

15. Haas, E., and Goldblatt, H. Renin content of kidneys in experimental renal and human essential hypertension. Amer. J. Physiol. 1959, 197, 1103.

16. Cowdry, E. V. Laboratory Technique in Biology and Medicine, 3rd ed. Baltimore, Williams and Wilkins, 1952, p. 382.

17. Hartroft, P. M., and Hartroft, W. S. Studies on renal juxtaglomerular cells; correlation of the degree of granulation of the juxtaglomerular cells with the width of the zona glomerulosa of the adrenal cortex. J. exp. Med. 1955, 102, 205.

18. Deane, H. W., and Masson, G. M. C. Adrenal cortical changes in rats with various types of experimental hypertension. J. clin. Endocr. 1951, 11, 193.

19. Pitcock, J. A., and Hartroft, P. M. The juxtaglomerular cells in man and their relationship to the level of plasma sodium and to the zona glomerulosa of the adrenal cortex. Amer. J. Path. 1958, 34,863 .

20. Hartroft, P. M., Newmark, L. N., and Pitcock, J. A. Relationship of renal juxtaglomerular cells to sodium intake, adrenal cortex and hypertension in Hypertension, J. H. Moyer, Ed. Philadelphia, W. B. Saunders, 1959, p. 24.

21. Gross, F. Renin und Hypertensin, physiologische oder pathologische Wirkstoffe? Klin. Wschr. 1958, 36, 693.

22. Kuhn, C., Hartroft, P. M., and Pitcock, J. A. Effects of renal extracts on juxtaglomerular cells, renin content, and zona glomerulosa. Fed. Proc. 1961, 20, 404.

23. Peart, W. S. Renin and hypertensin. Ergebn. Physiol. 1959, 50, 409.

24. Tobian, L. Interrelationship of electrolytes, juxtaglomerular cells and hypertension. Physiol. Rev. 1960, 40, 280.

25. Pitcock, J. A., Hartroft, P. M., and Newmark, L. N. Increased renal pressor activity (renin) in sodium deficient rats and correlation with juxtaglomerular cell granulation. Proc. Soc. exp. Biol. (N. Y.) 1959, 100, 868.

26. Merrill, A. J., Morrison, J. L., and Brannon, E. S. Concentration of renin in renal venous blood in patients with chronic heart failure. Amer. J. Med. 1946, 1, 468.

27. Dexter, L., Frank, H. A., Haynes, F. W., and Altschule, M. D. Traumatic shock. VI. The effect of hemorrhagic shock on the concentration of renin and hypertensinogen in the plasma in unanesthetized dogs. J. clin. Invest. 1943, 22, 847.

28. Davis, J. O., Goodkind, M. J., and Ball, W. C., Jr. Functional changes during high output failure produced by daily hemorrhage in dogs with pulmonic stenosis. Circulat. Res. 1957, 5, 388. 